\title{
Concentrations of Some Trace Elements in Vegetables Sold at Maun Market, Botswana
}

\author{
Keagile Bati ${ }^{1}$, Oarabile Mogobe ${ }^{2} \&$ Wellington R. L. Masamba ${ }^{2}$ \\ ${ }^{1}$ Department of Biological Sciences, University of Botswana. Botswana \\ ${ }^{2}$ Okavango Research Institute, University of Botswana. Botswana
}

Correspondence: Oarabile Mogobe, Okavango Research Institute, Private Bag 285, Maun, Botswana. Tel: 267-681-7211. E-mail: omogobe@ori.ub.bw

Received: October 29, 2016

Accepted: November 23, 2016 Online Published: December 20, 2016

doi:10.5539/jfr.v6n1p69

URL: http://dx.doi.org/10.5539/jfr.v6n1p69

\begin{abstract}
Contamination of vegetables with toxic metals is one of the most important contributing factors to ill health throughout the world, more so because vegetables are considered essential for human health and their consumption is highly recommended by health authorities. The aim of this study was to determine the concentrations of selected essential elements $(\mathrm{Fe}, \mathrm{Cu}, \mathrm{Mn}, \mathrm{Mo}, \mathrm{Zn})$ and toxic elements $(\mathrm{As}, \mathrm{Cd}, \mathrm{Cr}, \mathrm{Pb})$ in common vegetables sold for human consumption in supermarkets and open market of Maun village, Botswana. Five vegetables (cabbage, rape, tomatoes, onions and potatoes) were purchased from different selling points, washed with de-ionised water, cut into small pieces and digested with aqua regia on a block digester, following the US. EPA method 200 - 7 and analysed for metal content using Inductively Coupled Plasma - Atomic Emission Spectroscopy (ICP-AES). The results showed that concentrations of essential and toxic metals varied with the type of vegetable and also with the market category (supermarket or street vendor). The highest concentration of essential elements was obtained from cabbage with a $\mathrm{Zn}$ concentration of $135.4 \mathrm{mg} / \mathrm{Kg}$ and the lowest was from onion with a Mo concentration of $1.35 \mathrm{mg} / \mathrm{Kg}$. For toxic elements the highest concentration was obtained from rape vegetable with a $\mathrm{Pb}$ concentration of $4.73 \mathrm{mg} / \mathrm{Kg}$ and the lowest from the same vegetable with $\mathrm{Cr}$ concentration below the detection limit. Also observed was that leafy vegetables, especially cabbage, had the highest concentrations of most trace metals. It was concluded that vegetables sold in Maun had sufficient levels of essential elements but also some had high concentrations of toxic metals. We thus recommend consumption of vegetables from the studied markets with reduced frequency to avoid metal poisoning.
\end{abstract}

Keywords: trace metals, vegetables, aqua regia

\section{Introduction}

Food quality and safety has become a global concern due to contamination of food products with toxins such as pesticides, heavy metals, mycotoxins and other microbiological contaminants (WHO, 2003; Kumar et.al, 2012). Agricultural produce, free of chemical contaminants is therefore one of the most important aspects of food safety since consumption of food products contaminated with metals may pose health risks to people. The sources of metal contaminants in food such as vegetables occurs through anthropogenic activities like mining, metal and chemical industries, motor vehicle emissions as well as agricultural practices like use of inorganic fertilizers (Das et.al, 2008).

The contamination of vegetables may also occur from irrigating with sewage and industrial water. These metals accumulate in agricultural soils, taken up by vegetable crops and get transferred to humans through consumption of vegetables. Examples of these trace elements include iron $(\mathrm{Fe})$, copper $(\mathrm{Cu})$, cobalt $(\mathrm{Co})$, arsenic $(\mathrm{As})$, mercury $(\mathrm{Hg})$, gold $(\mathrm{Au})$, silver $(\mathrm{Ag})$ and others (Kumar et.al, 2012). Some of these elements ( $\mathrm{Fe}, \mathrm{Cu}, \mathrm{Ni}, \mathrm{Zn})$ are common in our environment and diet and are actually necessary for good health. However, when they occur in high concentrations, they may cause acute or chronic toxicity (Das et.al, 2008) . Some metals like Pb, $\mathrm{Hg}$, and $\mathrm{Cr}$ are toxic even at low concentrations and have been associated with many health issues like cancers, biochemical disorders and diseases of the nervous system (Orisakwe et al., 2012).

Trace elements such as Cadmium (Cd), Arsenic (As) and Chromium (Cr) have been listed by the World Health 
Organization (WHO) as carcinogens while mercury $(\mathrm{Hg})$ and Lead $(\mathrm{Pb})$ are associated with the developmental disorders in children (Sharma et.al, 2008; Singh et al. 2011). Studies carried out in various countries, investigating the impact of daily intake of vegetables contaminated with toxic metals, showed a strong correlation with prevalence of different types of cancers and other health issues like bone and the nervous system disorders, (Hough et al., 2004; Kumar, et.al, 2012; Türkdoğan et.al, 2003). The aim of this study was to assess the concentrations of some trace elements $(\mathrm{Fe}, \mathrm{Cu}, \mathrm{Pb}, \mathrm{Cr}, \mathrm{Cd}, \mathrm{As}, \mathrm{Mn}, \mathrm{Mo}$, and $\mathrm{Zn}$ ) in selected vegetables purchased from Maun central market area, in Botswana and assess their safety and potential contribution to good health.

\section{Materials and Methods}

\subsection{Study Area}

The study was conducted in Maun, a major town of Ngamiland District in the north west of Botswana (figure 1). Maun has a population of 60, 263 (CSO, 2011). The town is located in a tourism destination area, where most tourists pass through and spend some time before proceeding to the famous Okavango Delta. Although there are no chemical or metal industries within the area, use of inorganic fertilizers in commercial arable farming is common. Also, with its relatively high population, exposure to metal contaminants in vegetables needs investigation in order to protect the population from metal poisoning. Vegetables in the markets here are basically from two main sources; local suppliers and imports from South Africa.

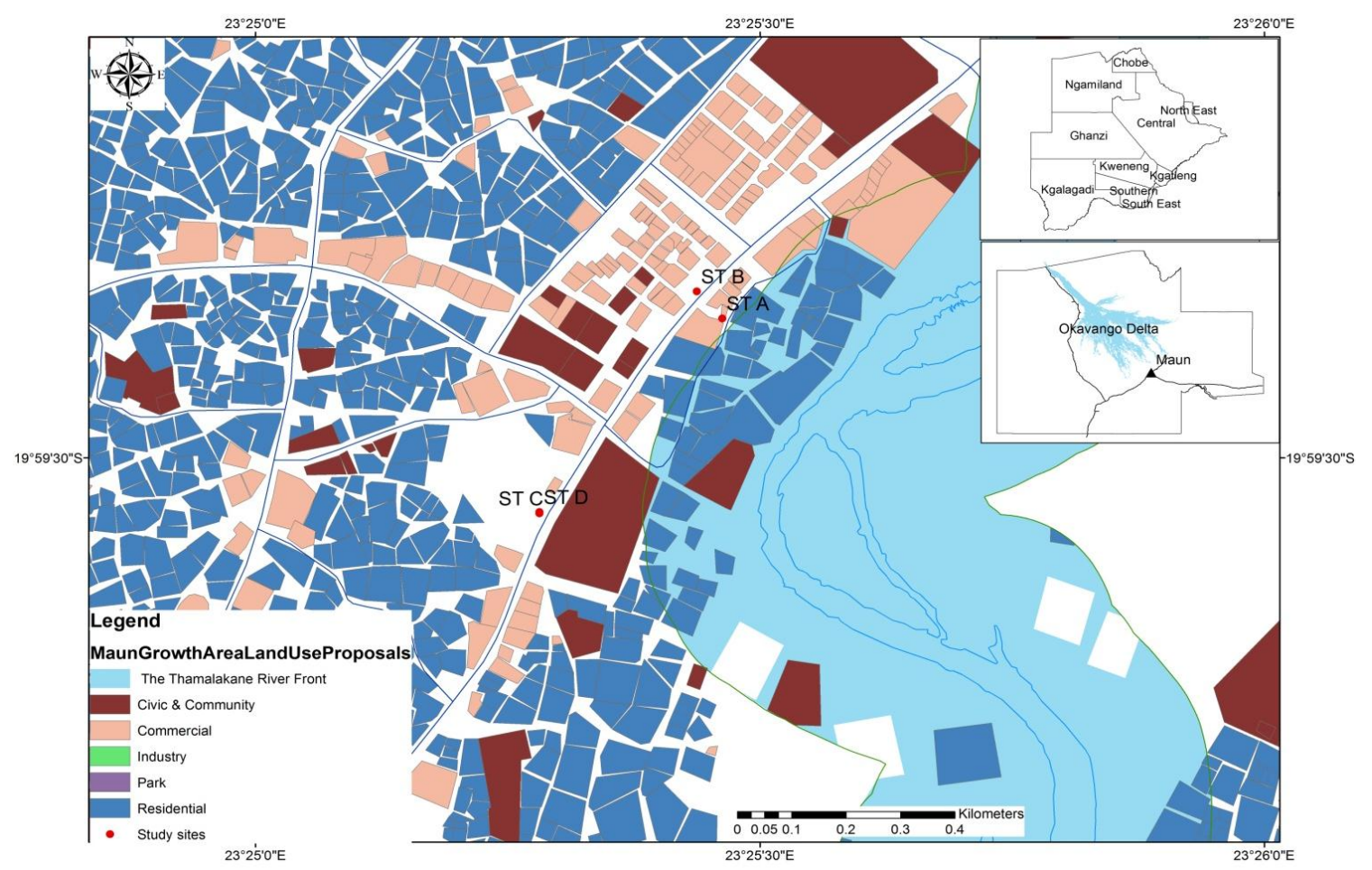

Figure 1. Location of the study area (Maun)

\subsection{Chemicals and Reagents}

All chemicals and reagents used were of analytical grade and purchased from Sigma - Aldrich company (USA). $37 \%$ hydrochloric acid $(\mathrm{HCL})$ and $65 \%$ nitric acid $\left(\mathrm{HNO}_{3}\right)$ were used for digestion of the samples. Calibration standards were prepared from single element $(1000 \mathrm{ppm})$ standard solutions of each element analysed. Internal quality control samples were used for quality assurance.

\subsection{Instrument and Apparatus}

Inductively coupled plasma optical emission spectrophotometer (ICP-OES), model Perkin Elmer, Optima 2100 with auto-sampler of model S10 was used for analyzing the trace metals of interest. All glassware were soaked overnight in $0.1 \mathrm{M}$ nitric acid and then rinsed with deionized water to reduce chances of contamination and any other interference. 


\subsection{Sample Collection and Treatment}

Vegetables were purchased from street vendors and supermarkets across the main market area of Maun. Names of vegetables purchased are shown in table 1 . They were separated and placed into large labelled polyethylene sampling bags and transported to the Environmental laboratory at Okavango Research Institute for analysis. Vegetables were first washed with fresh running water to remove dirt, soil sediments and other surface contaminants as in Shah et al, 2013. The edible parts (table 1) were then further washed with deionized water, cut into small pieces, and then dried overnight in oven at $40{ }^{\circ} \mathrm{C}$. The dried samples were crushed and ground to powder using a clean mortar and pestle. The ground samples were put in well labelled polyethylene bags and kept at $4{ }^{\circ} \mathrm{C}$ awaiting further processing (Mapanda et al., 2005).

Table 1. Sampled vegetables and their characteristics

\begin{tabular}{lllll}
\hline English Name & Scientific Name & Family & Part used & n \\
\hline Cabbage & Brassica oleracea var. capitata & Brassiaceace & Leaf & 12 \\
Rape & Brassica napus & Brassiaceace & Leaf & 27 \\
\hline Tomatoes & Solanum lycopersicum & Solanaceace & Fruit & 27 \\
\hline Onion & Allium Cepa & Alliaceace & Bulb & 27 \\
\hline Potatoes & Solanum tuberosum & Solanaceace & Tuber & 12 \\
\hline
\end{tabular}

\subsection{Sample Digestion and Analysis}

Extraction of metals from the samples was done by aqua regia following a method described by Taghipour and Mosaferi, (2013) with minor modifications. About $1.0 \pm 0.01 \mathrm{~g}$ of the powdered samples were put into labelled digestion tubes to which aqua regia in ratio 3: $1\left(12 \mathrm{~mL}\right.$ of conc. $\mathrm{HCl}+4 \mathrm{~mL}$ of conc. $\left.\mathrm{HNO}_{3}\right)$ was added. The contents were then mixed by swirling and then covered with digestion tube glass covers and allowed to stand for at least 12 hours in a fume cupboard. The digestion tubes containing the sample solutions were placed on a digestion block under fume-hood and heated at $95{ }^{\circ} \mathrm{C}$ for 30 minutes. The samples were then cooled and filtered using a Whatman $47 \mathrm{~mm}$ filter paper. The filtrates were topped to $100 \mathrm{~mL}$ in volumetric flasks using $0.1 \mathrm{M}$ $\mathrm{HNO}_{3}$. An internal control sample (P124) was digested together with the samples. Prior to analysis calibration standard solutions of 1,3 and $5 \mathrm{ppm}$ for the metals were prepared from $1000 \mathrm{ppm}$ stock solutions by pipetting the required volume into a $100 \mathrm{~mL}$ volumetric flask and diluting to the mark using $0.1 \mathrm{M}$ Nitric acid $\left(\mathrm{HNO}_{3}\right)$. All samples were then analysed in triplicates for presence of trace metals using ICP-OES based on recommended wavelengths.

\subsection{Statistical Analysis}

Statistical analyses were conducted using Sigma Plot software, version 11. Mean and standard error were computed and expressed in $\mathrm{mg} / \mathrm{Kg}$ dry weight of vegetables.

\section{Results and Discussion}

The results obtained from this study are presented in Tables 2 and 3. The sellers communicated that most vegetables sold by street vendors were grown in small gardens by small scale farmers along the local Thamalakane River. Some of the vegetables sold by these street vendors were actually harvested from their backyard gardens under the government poverty eradication scheme. On the other hand, supermarkets purchased their vegetables from large scale farmers in the country and imports from Zambia, Zimbabwe and South Africa. All potatoes sold by supermarkets were from South Africa. It was observed that distribution of metals in vegetables was not uniform as some vegetables recorded high concentrations of certain metals. This can be attributed to different crops having differing mineral uptake and accumulation and also different agricultural practices. It is also apparent from the results given on Table 2 that vegetables from supermarkets had higher concentrations of essential and toxic elements compared to those from street vendors. These differences were not statistically significant $(\mathrm{P}>0.05)$ and they may be due to the fact that commercial farmers tend to opt for intensive production practices, that is use of fertilizers, pesticides and wastewater for irrigation. All these products contain high levels of nutrients and minerals. 
Table 2. Concentrations of essential elements $(\mathrm{mg} / \mathrm{Kg})$ in vegetables from street vendors (STV) and supermarkets (SP)

\begin{tabular}{lllllll}
\hline Vegetable & Seller & Zn & Fe & Cu & Mn & Mo \\
\hline \multirow{2}{*}{ Brassica napus } & STV & $27.8 \pm 1.85$ & $76.8 \pm 3.81$ & $2.73 \pm 0.27$ & $70.2 \pm 4.35$ & $8.41 \pm 4.00$ \\
& SP & $47.3 \pm 4.99$ & $94.5 \pm 9.99$ & $5.63 \pm 0.37$ & $51.1 \pm 4.84$ & $2.83 \pm 0.29$ \\
\hline \multirow{2}{*}{ Solanum lycopersicum } & STV & $27.9 \pm 3.22$ & $55.7 \pm 8.01$ & $9.56 \pm 0.79$ & $17.9 \pm 1.74$ & $8.68 \pm 4.00$ \\
\cline { 2 - 7 } & SP & $45.5 \pm 5.72$ & $119.6 \pm 32.8$ & $14.7 \pm 6.09$ & $19.1 \pm 1.40$ & $3.19 \pm 0.23$ \\
\hline \multirow{2}{*}{ Allium cepa } & STV & $23.8 \pm 2.20$ & $40.7 \pm 3.28$ & $8.79 \pm 0.57$ & $18.4 \pm 2.24$ & $1.35 \pm 0.08$ \\
\cline { 2 - 7 } Brassica oleracea var. capitata & SP & $40.1 \pm 6.23$ & $59.7 \pm 3.94$ & $3.19 \pm 0.33$ & $19.8 \pm 0.70$ & $1.73 \pm 0.13$ \\
\hline Solanum tuberosum & SP & $135.4 \pm 12.1$ & $33.1 \pm 4.91$ & $8.06 \pm 0.71$ & $38.6 \pm 2.09$ & $5.79 \pm 0.94$ \\
\hline Valus & $89.8 \pm 5.98$ & $54.6 \pm 3.40$ & $2.57 \pm 0.12$ & $17.2 \pm 0.45$ & $1.79 \pm 0.08$ \\
\hline
\end{tabular}

Values are mean \pm standard error, BDL: below detection level $(<5 \mu \mathrm{g} / \mathrm{L})$

Table 3. Concentrations of toxic metals ( $\mathrm{mg} / \mathrm{Kg}$ ) in vegetables from street vendors (STV) and supermarkets (SP)

\begin{tabular}{llllll}
\hline Vegetable & Seller & Cr & Cd & Pb & As \\
\hline Brassica napus & STV & BDL & $0.31 \pm 0.02$ & $0.88 \pm 0.07$ & $4.82 \pm 2.96$ \\
& SP & $2.02 \pm 0.62$ & $0.53 \pm 0.05$ & $4.73 \pm 0.50$ & $1.83 \pm 0.07$ \\
\hline Solanum lycopersicum & STV & $0.07 \pm 0.04$ & $0.38 \pm 0.03$ & $1.42 \pm 0.05$ & $1.21 \pm 0.31$ \\
\cline { 2 - 6 } & SP & $0.95 \pm 0.12$ & $0.33 \pm 0.02$ & $0.88 \pm 0.05$ & $0.97 \pm 0.29$ \\
\hline Allium cepa & STV & $0.003 \pm 0.00$ & $0.33 \pm 0.02$ & $1.62 \pm 0.13$ & $2.91 \pm 0.10$ \\
\cline { 2 - 6 } & SP & $1.01 \pm 0.02$ & $0.36 \pm 0.04$ & $1.39 \pm 0.06$ & $2.95 \pm 0.89$ \\
\hline Brassica oleracea var. capitata & SP & $0.36 \pm 0.06$ & $0.80 \pm 0.05$ & $4.65 \pm 0.34$ & $4.50 \pm 0.10$ \\
\hline Solanum tuberosum & SP & $0.98 \pm 0.02$ & $0.61 \pm 0.05$ & $3.62 \pm .028$ & $1.52 \pm 0.16$
\end{tabular}

Values are mean \pm standard error, BDL: below detection level $(<5 \mu \mathrm{g} / \mathrm{L})$.

Table 4. Recommended dietary allowances (RDA) and Adequate Intake (AI) for trace elements studied based on WHO (1989) and FDA (2001) standards

\begin{tabular}{ll}
\hline Element & RDA \\
\hline Zinc & $12-15 \mathrm{mg} /$ day (RDA) \\
Iron & $8-18 \mathrm{mg} /$ day (RDA) \\
Copper & $0.2-1.3 \mathrm{mg} /$ day (RDA) \\
Manganese & $1.8-2.3 \mathrm{mg} /$ day (RDA) \\
Molybdenum & $2-50 \mu \mathrm{g} /$ day (AI) \\
Lead & $<250 \mu \mathrm{g} /$ day (AI) \\
Chromium & $20-25 \mu \mathrm{g} / \mathrm{day}(\mathrm{AI})$ \\
Cadmium & 0.5 to $0.8 \mu \mathrm{g} / \mathrm{L}(\mathrm{AI})$ \\
Arsenic & $50 \mu \mathrm{g} / \mathrm{L}($ water) $(\mathrm{AI})$ \\
\hline
\end{tabular}

\subsection{Distribution of Metals in Different Vegetables}

\subsubsection{Zinc}

The concentration of zinc in vegetables collected from street vendors was found to range from $13.24 \pm 0.68$ $\mathrm{mg} / \mathrm{Kg}$ in onions to $65.80 \pm 6.86 \mathrm{mg} / \mathrm{Kg}$ in tomatoes. From supermarkets, zinc concentrations were in the range $17.74 \pm 0.15 \mathrm{mg} / \mathrm{Kg}$ to $185.12 \pm 5.08 \mathrm{mg} / \mathrm{Kg}$ in onions and cabbages respectively. In all samples, some vegetables recorded zinc concentration above the permissible limit of zinc in plants, which is $50 \mathrm{mg} / \mathrm{Kg}$ (WHO, 2007). Other studies (Taghipour \& Mosaferi 2013, Harmanescu et al. 2011 and Arora et al. 2008) obtained zinc concentration ranges of $10-50 \mathrm{mg} / \mathrm{Kg}, 22.7-138.7 \mathrm{mg} / \mathrm{Kg}$ and $21-46 \mathrm{mg} / \mathrm{Kg}$ in Iran, Romania and India respectively in the same type of vegetables and these results are comparable to values obtained in this study. Therefore, based on the determined concentrations of zinc, consumption of $100 \mathrm{~g}$ of most vegetables analyzed would provide more than $100 \%$ of the daily required amount of zinc for good health shown on Table 4, hence they are nutritious especially for pregnant and lactating mothers who need at least $14 \mathrm{mg} \mathrm{Zn/day.} \mathrm{Zinc} \mathrm{is} \mathrm{known}$ to be a cofactor of many enzymes involved in metabolic pathways and important in cellular growth hence an important trace element for human life. However, overconsumption of the vegetables would be unsafe due to the 
tendency of zinc interfering with copper metabolism (Umar et al., 2014). The high concentrations of zinc in vegetables may be associated with rampant use of zinc fertilizers and metal based pesticides (Singh et al., 2010).

\subsubsection{Iron}

This study found out that the concentration of iron in vegetables bought from street vendors was in the range $7.98-122.7 \mathrm{mg} / \mathrm{Kg}$ and $17.7-177.8 \mathrm{mg} / \mathrm{Kg}$ for those purchased from supermarkets. The lowest concentration of iron recorded was $7.98 \mathrm{mg} / \mathrm{Kg}$ in tomatoes obtained from street vendors while the highest concentration of iron was $177.8 \mathrm{mg} / \mathrm{Kg}$ in rape obtained from supermarket stores. The permissible concentration limit of iron in plants is $20 \mathrm{mg} / \mathrm{Kg}$ (WHO, 2007) therefore some of the investigated vegetables have concentrations above the permissible limit. A study by Umar et al. (2014) found the mean concentration of iron in onions as $139.383 \pm 13$ $\mathrm{mg} / \mathrm{Kg}$ which is higher than the result of this study. Concentration of iron in cabbage was in the range $16-60$ $\mathrm{mg} / \mathrm{Kg}$. Iron is important in the human diet as it facilitates the oxidation of fats, proteins and carbohydrates to control body weight which is an important factor in diseases like diabetes. It also plays a pivotal role in the transportation of oxygen around the body. The recommended dietary allowance of Fe is $8-18 \mathrm{mg} / \mathrm{day}$ (FDA, 2001) shown on table 4, therefore; the studied vegetables are able to sustain the daily requirement of $\mathrm{Fe}$ in the body for consumption of a $100 \mathrm{~g}$ portion of vegetables. The vegetables are also suitable for pregnant and lactating mothers who require at least $27 \mathrm{mgFe} /$ day (WHO, 2003).

\subsubsection{Copper}

The concentration of copper in vegetables collected from the street vendors were in the range $1.14-14.8 \mathrm{mg} / \mathrm{kg}$ of which the lowest concentration $(1.14 \mathrm{mg} / \mathrm{Kg})$ was recorded in rape while the highest concentration of 14.8 $\mathrm{mg} / \mathrm{Kg}$ recorded in tomatoes. On the other hand, concentrations of copper in vegetables obtained from supermarkets ranged between $1.28-61.93 \mathrm{mg} / \mathrm{Kg}$ with the least concentration in tomatoes and the highest still in tomatoes. Concentrations of copper were found in the range of $0.75-2.00 \mathrm{mg} / \mathrm{Kg}$ in tomatoes grown in Glen Valley farms in Botswana (Dikinya \& Areola, 2010). Harmanescu et.al, (2011) found mean concentrations of $1.77 \pm 0.23,1.37 \pm 0.14 \mathrm{mg} / \mathrm{Kg}$ of copper in cabbage and onions. The permissible limit of copper in plants is 10 $\mathrm{mg} / \mathrm{Kg}$ (WHO, 2007) and vegetables sold by street vendors were within the limit, except for solanum lycopersicum $(14.7 \pm 6.09)$ sold by supermarkets. However, some vegetables, like some cabbages and rape sold by supermarkets were above the permissible limit. The recommended dietary allowance of copper by the Food and Drug Administration (FDA) is $0.7-0.9 \mathrm{mg} /$ daily for a normal adult body (FDA, 2001). Therefore, based on the mean concentrations of copper in all analyzed vegetables a $100 \mathrm{~g}$ portion of vegetables is able to supply the daily required amount of copper to the human body without need for use of supplements. Adequate amounts of copper are needed for a healthy body as it is very vital in the functioning of the liver and kidneys (Arif et al, 2011).

\subsubsection{Manganese}

Manganese is an important trace element in the human body. It acts as a catalyst and cofactor in many enzymatic processes involved in the synthesis of fatty acids and glycoproteins which coat body cells and protect against invading pathogens (Umar et al., 2014). Results of this study found out that in vegetable samples collected from street vendors, the concentration of manganese was in the range $9.05-95.7 \mathrm{mg} / \mathrm{Kg}$ with high concentrations in rape. However, for supermarkets the concentrations were in the range $11.1-49.9 \mathrm{mg} / \mathrm{Kg}$. Other studies (Harmanescu et al., 2011) obtained concentrations of $4.07 \pm 0.5,10.47 \pm 1.5 \mathrm{mg} / \mathrm{Kg}$ for onions and cabbages respectively. The recommended dietary allowance for manganese is $1.800-2.300 \mathrm{mg} / \mathrm{day}$ (FDA, 2001) and the obtained concentrations shows that the analyzed vegetables can individually sustain the required daily intake on just a 100g portion. Intake of lower than the required amount of manganese can result in manganese deficiency which causes defective muscular coordination and retarded nerve development and function (Liu et al., 2013).

\subsubsection{Molybdenum}

Analytical results of this study shows that the concentrations of molybdenum in vegetable samples collected from street vendors were in the range $0.31-54.6 \mathrm{mg} / \mathrm{Kg}$ while vegetable samples collected from supermarkets had concentrations in the range $1.02-13.7 \mathrm{mg} / \mathrm{Kg}$. The highest concentration of molybdenum in vegetables obtained from street vendors was 54.6 and $52.1 \mathrm{mg} / \mathrm{Kg}$ were recorded in rape and tomatoes respectively. The recommended dietary allowance for molybdenum is $34-45 \mu \mathrm{g} / \mathrm{day}$ (FDA, 2001). Therefore based on the mean concentrations of each vegetable, it can be noted that consumption of $100 \mathrm{~g}$ portion each vegetable would provide more than $100 \%$ of the required daily intake. Molybdenum act as a cofactor in certain essential enzymes that play a vital role in carbohydrate metabolism, utilization of iron, sulfite detoxification, and uric acid formation (Balch and Balch, 1990). It has also been found out that molybdenum works with riboflavin (vitamin B2) to incorporate iron into hemoglobin hence playing a pivotal role in production of red blood cells (Powers, 
2003). Deficiency of molybdenum has been linked to sexual impotence in older males, mouth and gum diseases (Balch and Balch, 1990). However, according to the Institute of Medicine, Food and Nutrition Board, (2001) excessive amount of molybdenum in the body may result in anemia and low white blood cell counts due to lack of copper as it interferes with copper metabolism.

\subsubsection{Lead}

Lead is the most recognized toxic environmental pollutant. This has resulted in more studies being carried out to determine its source and effects on humans, hence formulation of stringent regulations like ban of leaded petrol worldwide (Wang, 2005). Toxic levels of lead have been associated with encephalopathy seizures and mental retardation (Umar et al., 2014). The results of this study show that vegetable samples collected from street vendors had concentrations of lead in the range $0.37-2.93 \mathrm{mg} / \mathrm{Kg}$ while those from supermarkets the concentration range was $0.52-8.89 \mathrm{mg} / \mathrm{Kg}$. Some of results were above the FAO/WHO maximum permissible limit that is $2 \mathrm{mg} / \mathrm{Kg}$. Rape and potatoes sold by supermarkets, had high concentrations of lead which was above the permissible limit and therefore regarded unsafe for human consumption. Other studies (Guerra et al. 2012; Harmanescu et al. 2011; Abbas et al. 2010; Yang et al. 2011) obtained ranges; $470-1660 \mu \mathrm{g} / \mathrm{Kg}, 4.5-21.8$ $\mathrm{mg} / \mathrm{Kg}, 18-150 \mu \mathrm{g} / \mathrm{Kg}$ and $6-16 \mathrm{mg} / \mathrm{Kg}$ in Brazil, Nigeria, Pakistan and China respectively.

\subsubsection{Chromium}

The concentrations of chromium in vegetable samples collected from street vendors were in the range $0.00-0.48$ $\mathrm{mg} / \mathrm{Kg}$. The highest concentration $(0.48 \mathrm{mg} / \mathrm{Kg})$ was obtained in tomatoes. However, many vegetables obtained from street vendors had chromium levels below the detection level. On the other hand, the concentration range of chromium in vegetable samples collected from supermarkets was $0.00-7.26 \mathrm{mg} / \mathrm{Kg}$, with highest concentration of $7.26 \mathrm{mg} / \mathrm{Kg}$ obtained in rape. Other studies, (Taghipour \& Mosaferi 2013; Maobe et al. 2012; Guerra et al. $2012 \mathrm{~b}$ ) obtained chromium concentrations in the range $0.32-10.96 \mathrm{mg} / \mathrm{Kg}, 58-118 \mu \mathrm{g} / \mathrm{Kg}$ and $7-43 \mu \mathrm{g} / \mathrm{Kg}$ in Iran, Kenya and Brazil, respectively. The adequate intake of chromium $20-25 \mu \mathrm{g} / \mathrm{day}$ (FDA, 2001) and therefore, some of the vegetables can provide more than the required concentration hence may result in toxic effects. At levels below $105 \mathrm{mg} /$ day (US EPA, 2010), chromium is important for effective insulin activity and DNA transcription (Guerra et al. 2012b). The maximum permissible limit of chromium in food is $2300 \mu \mathrm{g} / \mathrm{Kg}$ (FAO/WHO, 2003) therefore all vegetables analyzed were regarded as safe for human health as the concentrations of chromium were all below the maximum permissible limit.

\subsubsection{Cadmium}

Cadmium is a hazardous element which has been associated with various complications like bone de-calcification, renal, membrane and DNA damages (Guerra et al. 2012). Research studies have found that vegetables contribute about 70\% cadmium intake by humans, varying according to the level of consumption (Wagner, 1993 in Rivera-becerril et al. 2002). Results of this study show that the concentration of cadmium in vegetables collected from street vendors was in the range $0.18-0.56 \mathrm{mg} / \mathrm{Kg}$ while it was $0.19-1.00 \mathrm{mg} / \mathrm{Kg}$ for vegetable samples from supermarkets. Other studies (Dikinya \& Areola, 2010; Sharma et al, 2009) obtained concentrations in the ranges $0.04-0.14 \mathrm{mg} / \mathrm{L}, 0.10-4.30 \mathrm{mg} / \mathrm{Kg}$ in Botswana and India respectively. The permissible limit of cadmium in plants recommended by FAO/WHO is $0.02 \mathrm{mg} / \mathrm{Kg}$. The analyzed vegetables have concentrations above the permissible limit hence regarded as unsafe for human consumption

\subsubsection{Arsenic}

The concentrations of arsenic in vegetable samples collected from street vendors was in the range $0.24-45.5$ $\mathrm{mg} / \mathrm{Kg}$ while that of supermarkets was $0.08-12.0 \mathrm{mg} / \mathrm{Kg}$. Other studies (Baig and Kazi, 2012; Ramirez-Andreotta, 2013) obtained concentrations in the ranges; $962-4810 \mu \mathrm{g} / \mathrm{Kg}$ and $10-1960 \mu \mathrm{g} / \mathrm{Kg}$ in Pakistan and Arizona in United States of America respectively. The permissible limit by FAO/WHO for arsenic is $100 \mu \mathrm{g} / \mathrm{Kg}$ (Abbas et al., 2010) therefore; most of the analyzed vegetables were unsafe for consumption since the concentrations were above the permissible limits. Arsenic is extremely toxic and long term exposure results in health effects like cardiovascular diseases and diabetes (Abbas et al., 2010; Zhuang et al., 2009).

\section{Conclusion}

The concentrations of essential trace metals $(\mathrm{Zn}, \mathrm{Fe}, \mathrm{Mn}, \mathrm{Mo}, \mathrm{Cu})$ were found to be high enough to meet the recommended daily intake hence it was concluded that vegetables sold in Maun were good for human health and may contribute towards preventing nutritional mineral deficiencies in people who eat vegetables in Maun. Vegetables from supermarkets had higher concentrations of essential metals compared to vegetables from street vendors probably due to intensive use of fertilizers and wastewater for irrigation. In terms of toxic metals $(\mathrm{Pb}, \mathrm{Cr}$, $\mathrm{Cd}, \mathrm{As}$ ), concentrations greatly varied between vegetable type and source (vendors and supermarkets). 
Vegetables from street vendors generally had lower concentrations of toxic metals compared to the ones obtained from supermarkets. This could still be attributed to intensive use of fertilizers and pesticides by the more sophisticated farmers who supply supermarkets. From the results of this study, the conclusion is that most vegetables from Maun supermarkets have higher concentrations of both essential and toxic metals (above WHO acceptable limits) and therefore must be consumed less frequently to avoid metal poisoning. Vegetables from street vendors have good levels of essential minerals and lower concentrations of toxic metals and therefore can be consumed freely for promoting good health. It is also concluded that leafy vegetables accumulate the highest concentrations of both essential and toxic metals.

\section{Acknowledgements}

The authors would like to thank the Okavango Research Institute for funding this study.

\section{References}

Abbas, M., Parveen, Z., Iqbal, M., Riazuddin, M., Iqbal, S., Ahmed, M., \& Bhutto, R. (2010). Monitoring of toxic metals (cadmium, lead, arsenic and mercury) in vegetables of Sindh, Pakistan. Kathmandu University Journal of Science, Engineering and Technology.

Arif, I. A., Khan, H. A., Homaidan, A. A. Al, \& Ahamed, A. (2011). Determination of Cu , Mn , Hg , Pb and Zn in the Outer Tissue Washings, Outer Tissues, and Inner Tissues of Different Vegetables Using ICP-OES, 20(4), 835-841.

Arora, M., Kiran, B., Rani, S., Rani, A., Kaur, B., \& Mittal, N. (2008). Heavy metal accumulation in vegetables irrigated with water from different sources. Food Chemistry, 111(4), 811-815. https://doi.org/10.1016/j.foodchem.2008.04.049

Baig, J. A., \& Kazi, T. G. (2012). Translocation of arsenic contents in vegetables from growing media of contaminated areas. Ecotoxicology and Environmental Safety, 75(1), 27-32. http://dx.doi.org/10.1016/j.ecoenv.2011.09.006

Balch, J. F, \& Balch, P. A., (1990). Prescription for nutritional healing: A practical A-Z reference to drug-free remedies using vitamins, minerals, herbs \& food supplements. New York: Avery Publishing.

Central Statistics Office (CSO), 2011 Botswana Population and Housing Census, Alphabetical Index of Villages. http://www.cso.gov.bw/templates/cso/file/File/2011\%20Census\%20_Alphabetical\%20Index\%20_Populatio n\%20of\%20Villages.pdf (Accessed on 03/10/2016).

Das, N., Vimala, R., \& Karthika, P. (2008). Biosorption of heavy metals - An overview. Indian Journal of Biotechnology.

Dikinya, O., \& Areola, O. (2010). Comparative analysis of heavy metal concentration in secondary treated wastewater irrigated soils cultivated by different crops, 7(2), 337-346.

EPA. (2009). National Primary Drinking Water Regulations. Environmental Protection Agency. https://www.epa.gov/dwregdev/drinking-water-regulations-and-contaminants.

FAO/WHO. (1999). Codex Alimentarious Commission. Draft Maximum Levels for Lead. CX/FAC 00/24. Joint FAO/WHO Food Standards Programme Codex Committee on Food Additives and Contaminants.

FAO/WHO. (2003). Food and Agriculture Organization of the United Nations World Health Organization JOINT FAO / WHO EXPERT COMMITTEE ON FOOD ADDITIVES Sixty-first meeting, (52). Retrieved from Http;//www.who.com

FDA. (2001). Determination Of Food Contaminants. Food and Drug Administration. http://www.fda.gov/Food/GuidanceRegulation/GuidanceDocumentsRegulatoryInformation.

Guerra, F., Trevizam, A. R., Muraoka, T., Marcante, N. C., \& Caniatti-Brazaca, S. G. (2012). Heavy metals in vegetables and potential risk for human health. Scientia Agricola. https://doi.org/10.1590/S0103-90162012000100008

Harmanescu, M., Alda, L., Bordean, D., Gogoasa, I., \& Gergen, I. (2011). Heavy metals health risk assessment for population via consumption of vegetables grown in old mining area; a case study: Banat County, Romania. Chemistry Central Journal. https://doi.org/10.1186/1752-153X-5-64

Hough, R. L., Breward, N., Young, S. D., Crout, N. M. J., Tye, A. M., Moir, A. M., \& Thornton, I. (2004). Assessing potential risk of heavy metal exposure from consumption of home-produced vegetables by urban populations. Environmental Health Perspectives, 112(2), 215-221. https://doi.org/10.1289/ehp.5589 
Institute of Medicine, Food and Nutrition Board, (2001). Dietary reference intakes for vitamin A, vitamin K, arsenic, boron, chromium, copper, iodine, iron, manganese, molybdenum, nickel, silicon, vanadium, and zinc. Washington, DC: National Academy Press.

Kumar, A., Zaidi, A., Wani, P. A., Khan, M. S., \& Kurek, E. (2012). Toxicity of Heavy Metals to Legumes and Bioremediation. Management, 163-178. http://dx.doi.org/10.1007/978-3-7091-0730-0

Kumar, N., Soni, H., \& Kumar, R. (2010). Characterization of Heavy Metals in Vegetables Using Inductive Coupled Plasma Analyzer (ICPA). Journal of Applied Sciences and Environmental Management. http://dx.doi.org/10.4314/jasem.v11i3.55131

Liu, X., Song, Q., Tang, Y., Li, W., Xu, J., Wu, J., ... Brookes, P. C. (2013a). Human health risk assessment of heavy metals in soil-vegetable system: A multi-medium analysis. Science of the Total Environment. http://dx.doi.org/10.1016/j.scitotenv.2013.06.064

Liu, X., Song, Q., Tang, Y., Li, W., Xu, J., Wu, J., ... Brookes, P. C. (2013b). Human health risk assessment of heavy metals in soil-vegetable system: A multi-medium analysis. Science of the Total Environment. http://dx.doi.org/10.1016/j.scitotenv.2013.06.064

Maobe, M. A. G., Gatebe, E., Gitu, L., \& Rotich, H. (2012). Profile of Heavy Metals in Selected Medicinal Plants Used for the Treatment of Diabetes, Malaria and Pneumonia in Kisii Region, Southwest Kenya, 6(3), 245-251. http://dx.doi.org/10.5829/idosi.gjp.2012.6.3.65128.

Mapanda F, Mangwayana E, Nyamangara J, (2005). The effect of long-term irrigation using wastewater on heavy metal contents of soils under vegetables in Harare, Zimbabwe. Agr Ecosyst Env., 107(2-3), 151-165. https://doi.org/10.1016/j.agee.2004.11.005

Orisakwe, O. E., Kanayochukwu, N. J., Nwadiuto, A. C., Daniel, D., \& Onyinyechi, O. (2012). Evaluation of Potential Dietary Toxicity of Heavy Metals of Vegetables. http://dx.doi.org/10.4172/2161-0525.1000136

Powers H.J, (2003). Riboflavin (vitamin B-2) and health. American Journal of Clinical Nutrition, 77, 1352-60.

Ramirez-Andreotta, M. D., Brusseau, M. L., Artiola, J. F., \& Maier, R. M. (2013). A greenhouse and field-based study to determine the accumulation of arsenic in common homegrown vegetables grown in mining-affected soils. The Science of the Total Environment, 443, 299-306.

http://dx.doi.org/10.1016/j.scitotenv.2012.10.095

Rivera-becerril, F., Calantzis, C., Turnau, K., Caussanel, J., Belimov, A. A., Gianinazzi, S., ... Gene, D. (2002). Cadmium accumulation and buffering of cadmium-induced stress by arbuscular mycorrhiza in three Pisum sativum L . genotypes. Journal of Experimental Botany, 53(371), 1177-1185. https://doi.org/10.1093/jexbot/53.371.1177

Sharma, R. K., Agrawal, M., \& Marshall, F. M. (2009). Heavy metals in vegetables collected from production and market sites of a tropical urban area of India. Food and Chemical Toxicology, 47(3), 583-591. https://doi.org/10.1016/j.fct.2008.12.016

Singh, A., Sharma, R. K., Agrawal, M., \& Marshall, F. M. (2010). Health risk assessment of heavy metals via dietary intake of foodstuffs from the wastewater irrigated site of a dry tropical area of India. Food and Chemical Toxicology, 48(2), 611-619. https://doi.org/10.1016/j.fct.2009.11.041

Singh, R., Gautam, N., Mishra, A., \& Gupta, R. (2011). Heavy metals and living systems: An overview. Indian Journal of Pharmacology, 43(3), 246-253. https://doi.org/10.4103/0253-7613.81505

Taghipour, H., \& Mosaferi, M. (2013). Heavy metals in the vegetables collected from production sites. Health Promotion Perspectives, 3(2), 185-93. http://dx.doi.org/10.5681/hpp.2013.022

Türkdoğan, M. K., Kilicel, F., Kara, K., Tuncer, I., \& Uygan, I. (2003). Heavy metals in soil, vegetables and fruits in the endemic upper gastrointestinal cancer region of Turkey. Environmental Toxicology and Pharmacology. http://dx.doi.org/10.1016/S1382-6689(02)00156-4

Umar, M. A., Salihu, Z. O. O., \& Pepper, C. (2014). Heavy metals content of some spices available within FCT-Abuja , Nigeria . International Journal of Agricultural and Food Science, 4(1), 66-74.

Wang, X., Sato, T., Xing, B., \& Tao, S. (2005). Health risks of heavy metals to the general public in Tianjin, China via consumption of vegetables and fish. Science of the Total Environment.

http://dx.doi.org/10.1016/j.scitotenv.2004.09.044

WHO. (2003). Codex Alimentarius Commission Procedural Manual. 
http://www.fao.org/fao-who-codexalimentarius/procedures-strategies/procedural-manual/en.

WHO. (2007). Specifications for the identity and purity of food additives and their toxicologicalevaluation: some emulsifiers and stabilizers and certain other substances. Geneva: FAO and WHO.

Yang, Q. Wei, Xu, Y., Liu, S. Jiang, He, J. Feng, \& Long, F. Yan. (2011). Concentration and potential health risk of heavy metals in market vegetables in Chongqing, China. Ecotoxicology and Environmental Safety, 74(6), 1664-1669. https://doi.org/10.1016/j.ecoenv.2011.05.006

Zhuang, P., McBride, M. B., Xia, H., Li, N., \& Li, Z. (2009). Health risk from heavy metals via consumption of food crops in the vicinity of Dabaoshan mine, South China. Science of the Total Environment, 407(5), 1551-1561. https://doi.org/10.1016/j.scitotenv.2008.10.061

\section{Copyrights}

Copyright for this article is retained by the author(s), with first publication rights granted to the journal.

This is an open-access article distributed under the terms and conditions of the Creative Commons Attribution license (http://creativecommons.org/licenses/by/4.0/). 